\title{
PRÄSENTATION DER EUROPEAN OPEN SCIENCE CLOUD AN DER UNIVERSITÄT WIEN (WIEN, 23. NOVEMBER 2018)
}

\author{
von Bruno Bauer
}

Zusammenfassung: Am 23. November 2018 wurde im Rahmen der österreichischen EU-Ratspräsidentschaft die erste Version des Internet-Portals der „European Open Science Cloud" (EOSC) an der Universität Wien präsentiert. Vertreterinnen und Vertreter aus Politik, Wissenschaft und Forschungsförderung sowie der Europäischen Kommission sprachen über Konzept und Bedeutung der EOSC und stellten an konkreten Beispielen deren Potential vor. Im Rahmen dieser Veranstaltung wurde auch „The Vienna Declaration on the European Open Science Cloud" öffentlich vorgestellt.

Schlüsselwörter: Europäische Union; European Open Science Cloud; EOSC; Internet-Portal; e-Infrastrukturen; Vienna Declaration on the European Open Science Cloud; Universität Wien; 2018; Tagungsbericht

\section{LAUNCH OF THE EUROPEAN OPEN SCIENCE CLOUD AT THE UNIVERSITY OF VIENNA (VIENNA, NOVEMBER 23, 2018)}

Abstract: On November 23, 2018 the first version of the internet portal European Open Science Cloud (EOSC) was presented at the University of Vienna as part of the Austrian EU Council Presidency. Representatives from politics, science, research funding and the European Commission discussed the concept and meaning of the EOSC and presented its potential with concrete examples. As part of this event the Vienna Declaration on the European Open Science was also publicly presented.

Keywords: European Union; European Open Science Cloud; EOSC; internet portal; e-infrastructures; Vienna Declaration on the European Open Science Cloud; University of Vienna; 2018; event report

DOI: https://doi.org/10.31263/voebm.v71i3-4.2171

(C) Bruno Bauer

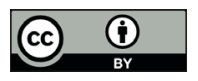

Dieses Werk ist lizenziert unter einer

Creative-Commons-Lizenz Namensnennung 4.0 International 


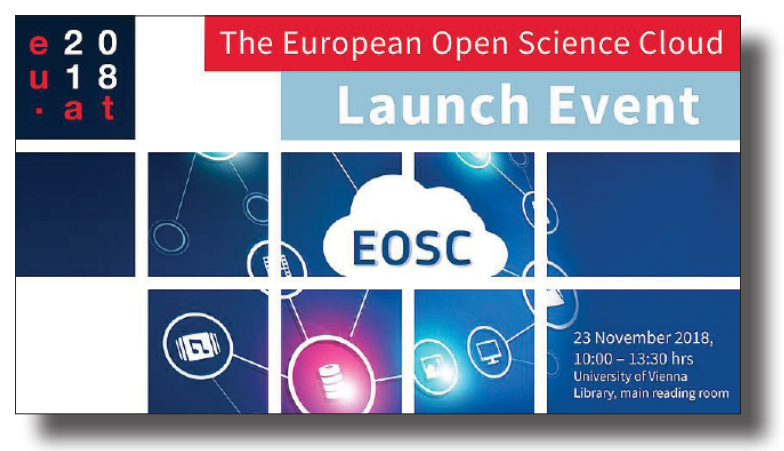

1,7 Millionen Forscherinnen und Forscher sowie 70 Millionen Expertinnen und Experten in Wissenschaft und Technologie in Europa produzieren laufend Daten. Allein von der Europäischen Union wurden in den letzten zehn Jahren Forschungsprojekte mit einer Fördersumme von mehr als 120 Milliarden Euro gefördert, aus denen auch große Datenmengen entstanden sind. Die Möglichkeit, diese sicher zu archivieren und wieder zu verwenden, wurde von der Europäischen Kommission als wichtiges Ziel formuliert. Nachdem die Vorarbeiten an einer European Open Science Cloud (EOSC) bereits 2015 gestartet worden waren ${ }^{1}$, erfolgte deren offizielle Ankündigung durch die Europäische Kommission im April 2016. ${ }^{2}$ Für die Entwicklung und den Aufbau der Cloud, deren Fertigstellung bis 2020 geplant ist, wurden über Horizon 2020600 Millionen Euro bereitgestellt.

Am 23. November 2018 fand im Rahmen der österreichischen EU-Ratspräsidentschaft der "Launch of the European Open Science Cloud" im historischen Lesesaal der Universitätsbibliothek der Universität Wien statt. ${ }^{3}$ Ziel der EOSC ist es, wie Heinz Faßmann, Bundesminister für Bildung, Wissenschaft und Forschung, in seiner Rede zur Eröffnung der Veranstaltung ausführte, öffentlich finanzierte Datensätze wieder öffentlich zugänglich zu machen und eine wichtigen Meilenstein für die europäische e-Infrastruktur zu setzen, die von „Openess“ geprägt ist. Das von europäischen Forscherinnen und Forschern produzierte und stetig steigende Datenvolumen, insbesondere im Rahmen von öffentlich geförderter Forschung, soll in einer offenen und sicheren Umgebung gespeichert und verwaltet werden, sodass es wieder verwendet werden kann.

Jean-Eric Paquet, Generaldirektor für Forschung und Innovation der EU-Kommission, erläuterte, dass die Daten nicht zentral gespeichert werden sollen; vielmehr wird im Rahmen der EOSC die Zusammenführung der bestehenden Infrastrukturen für Daten über die Grenzen von Ländern und Disziplinen hinweg angestrebt. Für die Daten sollen gemeinsame Stan- 
dards genutzt werden. Große Bedeutung kommt in diesem Zusammenhang den Prinzipien von FAIR zu, an denen sich die EOSC orientiert: Findable (auffindbar), Accessible (zugänglich), Interoperable (kompatibel), Re-usable (wiederverwendbar).

Paul Ayris, Vice- Provost der Library Services der University College London, wies auf die Chance für Europa hin, mit der aktuellen EOSC-Initiative im globalen Kontext eine führende Rolle im Bereich von Open Science einnehmen zu können. Auch er betonte die Bedeutung der FAIR-Prinzipien, die für die Aktivitäten der League of European Research Universities (LERU) maßgeblich sind, wie in der von der LERU im Mai 2018 veröffentlichten Roadmap für Open Science an Universitäten festgehalten wurde. ${ }^{4}$

In weiteren Beiträgen erläuterten Forscherinnen und Forschern anhand konkreter Beispiele europäischer Forschungseinrichtungen das Potential von Kooperationen im Bereich der Forschungsdaten und den Nutzen der EOSC. Die Bandbreite reichte von der Hirnforschung (hierzu sprach Katrin Amunts, Direktorin des Instituts für Neurowissenschaften und Medizin am Forschungszentrum Jülich, über die beeindruckende Kooperation wissenschaftlicher Einrichtungen in verschiedenen Ländern beim Human Brain Project) bis zu den Sprachwissenschaften (hierzu ließ Ruth Wodak, ehemalige Professorin für Sprachwissenschaften der Universität Wien und der Lancaster University, die rasante Entwicklung Revue passieren, die im Verlauf ihrer beruflichen Karriere eine immer effizienteres Arbeiten über Ländergrenzen hinweg ermöglicht hat).

Anschließend wurden von Jean-David Malo, Director for Open Innovation and Open Science, und Thomas Skordas, Director for Digital Excellence and Science Infrastructure, sowie weiteren Mitarbeiterinnen und Mitarbeitern der Europäischen Kommission die Governance und die erste Version des Portals der European Open Science Cloud vorgestellt: www.eosc-portal.eu.

Zum Abschluss der Veranstaltung, die vom Wiener Organisationskomitee (Paolo Budroni, Raman Ganguly, Stefan Hanslik, Barbara SanchezSolis, Pamela Stückler und Gerry Schneider) perfekt vorbereitet worden ist, präsentierten Bundesminister Heinz Faßmann, Karina Angelieva, stellvertretende Ministerin für Bildung und Forschung in Bulgarien, sowie Ciprian Preda, Staatssekretär für Forschung und Innovation in Rumänien, „The Vienna Declaration on the European Open Science Cloud"s.

Die Präsentationen und Videos zum EOSC Launch Event, das vom Bundesministerium für Bildung, Forschung und Wissenschaft, von der Universität Wien, der Technischen Universität Wien und der Europäischen Kommission veranstaltet wurde, sind über Phaidra, das Repositorium der Universität Wien, abrufbar. ${ }^{6}$ 


\section{The Vienna Declaration on the European Open Science Cloud}

Vienna, 23 November 2018

We, Ministers, delegates and other participants attending the launch event of the European Open Science Cloud (EOSC):

1) Recall the challenges of data driven research in pursuing excellent science as stated in the „EOSC Declaration" signed in Brussels on 10 July 2017.

2) Reaffirm the potential of the European Open Science Cloud to transform the research landscape in Europe. Confirm that the vision of the European Open Science Cloud is that of a research data commons, inclusive of all disciplines and Member States, sustainable in the long-term.

3) Recognise that the implementation of the European Open Science Cloud is a process, not a project, by its nature iterative and based on constant learning and mutual alignment. Highlight the need for continuous dialogue to build trust and consensus among scientists, researchers, funders, users and service providers.

4) Highlight that Europe is well placed to take a global leadership position in the development and application of cloud services for Science. Reaffirm that the European Open Science Cloud will be both European and open to the world, reaching out over time to relevant global research partners.

5) Recall that the Council - in its conclusions of 29 May 2018 - welcomed the implementation roadmap and the federated model for the European Open Science Cloud. It invited the Commission and all Member States to set up a common governance framework that ensures participation of stakeholders from the research community based on principles of transparency, openness and inclusiveness and an effective involvement of all Member States.

6) Note that the 2018 EOSC Summit (held on 11 June 2018) called for acceleration towards making the European Open Science Cloud a reality, hinting at the need to further strengthen the ongoing dialogue across institutions and with stakeholders, for a new governance framework to be launched in Vienna, on 23 November 2018. 


\section{We therefore:}

7) Resolve to harness the many ongoing and planned activities at EU and Member States level to cooperate in establishing an inclusive partnership with a view to developing the European Open Science Cloud as a federated infrastructure that can enhance value-based, open, trusted, user-centric digital services across borders within the Digital Single Market (DSM).

8) Invite all Member States, as well as public and private stakeholders in Europe, to support actively this joint effort and the new European Open Science Cloud governance structure for a successful implementation of the initiative.

9) Call for the European Open Science Cloud to provide all researchers in Europe with seamless access to an open-by-default, efficient and cross-disciplinary environment for storing, accessing, reusing and processing research data supported by FAIR data principles.

10) Commit to support service provision for the European Open Science Cloud by helping connecting relevant national and disciplinary nodes to the pan-European level.

11) Reaffirm the potential of the European Open Science Cloud to enable first-class data-driven science and to stimulate new business models benefiting our society and the economy. Recognise that such services will create opportunities for both public and private sectors, notably by intensifying reuse of public sector information while preserving data integrity, and ensuring access, transparency within and across borders.

We therefore declare to work together towards realising the potential of the European Open Science Cloud for the benefit of citizens, society and the economy.

The Vienna EOSC Declaration was conceived by Paolo Budroni, University of Vienna and Stefan Hanslik, Austrian Federal Ministry for Education in close cooperation with the European Commission. Vienna, 2018 
Mag. Bruno Bauer ORCID: https://orcid.org/0000-0002-4729-331X Medizinische Universität Wien, Universitätsbibliothek E-Mail: bruno.bauer@meduniwien.ac.at

1 European Commission: Realising the European Open Science Cloud. First report and recommendations of the Commission High Level Expert Group on the European Open Science Cloud. Luxembourg: Publications Office of the European Union, 2016. Online: https://ec.europa.eu/research/openscience/pdf/realising_the_european_open_science_cloud_2016.pdf

2 European Commission: European Cloud Initiative - Building a competitive data and knowledge economy in Europe. Communication from the Commission to the European Parliament, the Council, the European Economic and Social Committee and the Committee of the Regions. Brussels, 19.4.2016. Online: http://ec.europa.eu/newsroom/dae/document.cfm?doc_id=15266

3 Launch of the European Open Science Cloud. Vienna, 23rd November 2018. Online: https://eosc-launch.eu/home/

4 League of European Research Universities (Leru): Open Science and its role in universities: a roadmap for cultural change. Leuven, May 2018. Advice Paper No. 24. Online: https://www.leru.org/files/LERU-AP24Open-Science-full-paper.pdf

5 The Vienna Declaration on the European Open Science Cloud. Vienna, 23.11.2018. Online: https://phaidra.univie.ac.at/view/o:918643

6 The European Open Science Cloud: Launch Event. https://phaidra.univie.ac.at/detail_object/o:918650 